\title{
Editorial
}

\section{The promise of stem cells as corneal-transplant substitute}

\author{
Jeanne A. Pawitan \\ Department of Histology, Faculty of Medicine, Universitas Indonesia, Jakarta, Indonesia
}

In this issue, Asroruddin, et $\mathrm{al}^{1}$ reported their study on various factors affecting bacterial corneal ulcer healing, and concluded that the most common risk factor for corneal ulcer was trauma, and Pseudomonas sp. was the most common bacteria found in corneal ulcer. Most cases were healed by antibiotics and epithelial healing was complete after more or less 17.5 days. ${ }^{1}$ However, a corneal ulcer might be difficult to diagnose and the cause might be elusive, which causes delayed treatment, impaired healing and development of a large corneal scar that lead to visual acuity impairment or even blindness. ${ }^{2}$

Large corneal scar may need corneal transplantation, but shortage of corneal donor requires development of other means to substitute corneal transplant. Various attempts have been tried, and a very promising approach using umbilical cord derived stem cells was reported. ${ }^{3}$

Umbilical cord was shown to contain a very special type of stem cells that is called mucin secreting cord lining epithelial cells (muc-CLEC). This muc-CLEC was derived from umbilical cord tissue that wrapped the Wharton's jelly, namely the cord lining membrane. To get the muc-CLEC, cord lining membrane was minced to $0.5 \mathrm{~cm}^{2}$ squares and the explants were cultured in Medium-171. The medium is a commercial medium to grow mammary epithelium. Cell outgrowth was harvested and cryopreserved, and finally was cultured in a cocktail with PTTe-1 medium as the main medium. However, PTTe-1 is an inhouse medium that will be patented, and is not yet available commercially. ${ }^{4}$

The muc-CLEC was characterized and showed cytoplasmic or nuclear expression of p63, which was an epithelial cell marker that was expressed in corneal epithelium. Moreover, muc-CLEC express pluripotent stem cell marker, i.e. OCT-4 and NANOG in all of the cells, and around 70\% of the cells were positive for SSEA-4, SOX2, and REX1; and also mesenchymal stem cell (MSC) markers. However, the percentages of MSC markers were not precisely the same as in MSC, as muc-CLEC expressed very high CD166, moderate CD105, and low CD73 ${ }^{4}$ while according to International Society for Cell Therapy (ISCT) consensus, MSC should express more than 95\% CD105 and CD73. ${ }^{5}$ Further, muc-CLEC express HES1, ABCG2, BMI1, and CK15, ${ }^{3}$ and combination of the expression of these markers and p63 make them similar to limbal stem cells, which are the source of corneal epithelial cells. Moreover, other studies induced embryonic stem cells ${ }^{6}$ and bone marrow MSCs ${ }^{7}$ into corneal epithelium progenitors either using limbal stem cell conditioned medium and collagen IV as matrix, ${ }^{6}$ or limbal stem cell co-culture or conditioned medium. ${ }^{7}$

In a study, Reza, et $\mathrm{al}^{3}$ used muc-CLEC that were seeded on amniotic membrane and was supported by nitrocellulose frame, which was transplanted to a denuded area of a limbal stem cell deficient rabbit cornea. The frame was sutured to hold it on place. This treatment was compared to both amniotic membrane supported by nitrocellulose frame transplant, and no transplant as controls. The muc-CLEC transplanted eyes showed clear cornea with smooth surface, while both controls showed corneal epithelial defect, surface irregularity, and corneal opacification. ${ }^{3}$ Another study applied MSCs that were suspended in fibrin gel compared to fibrin gel only on rabbit scraped cornea, and showed corneal reconstruction in both MSC containing fibrin gel and fibrin gel only group.

In conclusion, stem cells from various sources were promising to be developed as corneal transplant substitutes. 


\section{REFERENCES}

1. Asroruddin M, Nora RLD, Edwar L, Sjamsoe S, Susiyanti M. Various factors affecting the bacterial corneal ulcer healing: A 4-years study in referral tertiary eye hospital in Indonesia. Med J Indones. 2015;24(3):150-5.

2. Kent C. Winning the battle against corneal ulcers. Review of ophthalmology [Internet]. Newton Square: Jobson Medical Information [update 2013 may 9; cited 2015 August 26]. Available from: http://www.reviewophtalmology.com/content/t/ cornea/c/42796/

3. Reza HM, Ng BY, Gimeno FL, Phan TT, Ang LPK. Umbilical cord lining stem cells as a novel and promising source for ocular surface regeneration. Stem Cell Rev and Rep. 2011;7:935-47.

4. Reza HM, Ng BY, Phan TT, Tan DTH, Beuerman RW,
Ang LPK. Characterization of a novel umbilical cord lining cell with CD227 positivity and unique pattern of P63 expression and function. Stem Cell Rev and Rep. 2011;7:624-38.

5. Dominici M, Le Blanc K, Mueller I, Slaper-Cortenbach I, Marini FC, Krause DS, et al. Minimal criteria for defining multipotent mesenchymal stromal cells. The International Society for Cellular Therapy position statement. Cytotherapy. 2006;8(4):315-7.

6. Ahmad S, Stewart R, Yung S, Kolli S, Armstrong L, Stojkovic M, et al. Differentiation of human embryonic stem cells into corneal epithelial-like cells by in vitro replication of the corneal epithelial stem cell niche. Stem Cells. 2007; 25:1145-55.

7. Gu S, Xing C, Han J, Tso MOM, Hong J. Differentiation of rabbit bone marrow mesenchymal stem cells into corneal epithelial cells in vivo and ex vivo. Molecular Vision. 2009;15:99-107.

pISSN: 0853-1773 • eISSN: 2252-8083 • http://dx.doi.org/10.13181/mji.v24i3.1280 • Med J Indones. 2015;24:131-2

Correspondence author: Jeanne A. Pawitan, jeanneadiwip@gmail.com

Copyright @ 2015 Authors. This is an open access article distributed under the terms of the Creative Commons Attribution-NonCommercialShareAlike 4.0 International License (http://creativecommons.org/licenses/by-nc-sa/4.0/), which permits unrestricted non-commercial use, distribution, and reproduction in any medium, provided the original author and source are properly cited. 